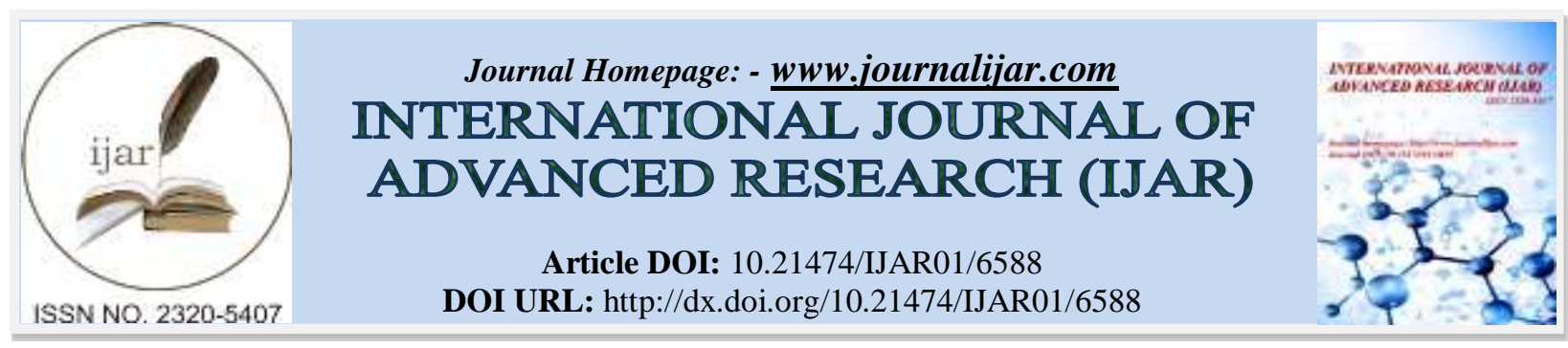

RESEARCH ARTICLE

\title{
JOURNEYS ACROSS TERRITORIES: A COMPARATIVE ANALYSIS OF THE LITERARY AND CINEMATIC TEXTS OF EAT, PRAY, LOVE.
}

\author{
Meera Babu. \\ Lecturer, Department of English, St. Dominics College, Kanjirapally, Kerala, India.
}

\section{Manuscript Info}

Manuscript History

Received: 19 December 2017

Final Accepted: 21 January 2018

Published: February 2018

Key words:-

adaptation, self discovery,

difference, flashback, translation.

\begin{abstract}
Film and novel are two different forms of art which are closely connected to each other. Both film and novel can be seen as a form of representational arts which depends on established codes and conventions of language. The study attempts a comparative analysis of the memoir and the movie, Eat, Pray, Love. It focuses on the features of the book and the film, various changes that has been made when the memoir was adapted, the journey of the protagonist and the cultural interventions that are portrayed in the memoir as well as the film.
\end{abstract}

\section{Introduction:-}

If poetry is what you cannot translate, as Robert Frost once suggested, then art is what you cannot define. Art covers a wide range of human endeavors such that it is almost an attitude than just an activity. Film and novel are two different forms of art which are closely connected to each other. Over the years many novels have been adapted into films. Both the film and the novel can been seen as a form of representational arts which depends on established codes and conventions of language. It conveys the information about a particular subject to the observer.

Films can be adaptations of books and are not always as great as their tangible copies. When a novel is adapted into a film it is not often a seamless transition, sometimes the readers can be surprised by the amount of similarities. Changes rarely favor the original elements in the story. There have been a number of great films based on memoirs: The Motorcycle Diaries, 127 Hours, My Week with Marilyn, The Piano, just to name a few. Sometimes, however, we can be surprised by the amount of differences, thus helping readers make their judgment on whether the novel or film is better.

A common form of film adaptation is the use of a novel as the basis of a feature film. Other works adapted into films include non-fiction, autobiography, comic books, plays, scripture, historical sources, and even other films. Adaptations may certainly be seen as "an interpretation, involving at least one person's reading of a text, choices about what elements to transfer, and decisions about how to actualize these elements in a medium of image and sound" (Desmond, Hawkes 2).

Elizabeth Gilbert's Eat, Pray, Love is an intriguing memoir on self discovery and is a story of overcoming a life crisis and finding personal balance again. A memoir is a written record of memories which emphasize on "... the people and events that the author has known or witnessed" (Abrams 31). The memoir was made into a film by the same name in 2010 and it was directed by Ryan Murphy. Both Elizabeth Gilbert and Ryan Murphy reveal Elizabeth 
as a as a frail individual who eventually finds her true self on a journey of self discovery. The memoir speaks in a clearer manner in helping readers understand the events without getting confused and sidetracked as opposed to the film.

Gilbert spends a total of one year traveling Italy, India and Indonesia. She enjoys her life and good food in Italy ("Eat"), taps into her inner spirituality in India ("Pray") and ultimately finds her balance in Indonesia ("Love"). Julia Roberts stars in the film as Elizabeth Gilbert. Overall, the movie adaptation tries to stay as close as possible to the original book to capture its very essence but it does not have quite the same impact.

The opening scene of the movie adaption can be described as follows: After Gilbert's divorce from her husband and break up with her lover, she was left alone. During that time she was sent to Bali and there she met Ketut, a ninth generation medicine man who told her in a self-fulfilling manner that she would spend the next year travelling the world and that they will spend some time studying together in Bali.

But Gilbert begins her memoir by describing about Giovanni and her strong bond with him. "I wish Giovanni would kiss me," is Gilbert's opening hook (7). Giovanni is her Italian language master, whose charm is only increased by the fact that he is much younger, tall, dark and handsome and has an equally charming, tall, dark and handsome twin. But, she proceeds to explain why this is a bad idea. It is not that she has any moral compunction about having twin lovers, but that she has decided that, in her search for healing and peace, a year of celibacy is necessary medicine.

Eat, Pray, Love logistically may seem as faithful adaptation of Elizabeth Gilbert's memoir, but the emotional core of Elizabeth's journey has been given complete Hollywood makeover resulting in an emotionally uneasy adaptation of the book's main content. Mainly three steps are involved in it, namely, beautification intensification and simplification.

Naturally, any Hollywood makeover includes a lot of waxing, tweezing, shaping and editing. The Elizabeth Gilbert that emerges from this process is the classic Hollywood pretty woman Julia Roberts. And Felipe, the 52 year old Brazilian we meet in Bali is now the younger, fitter, beautiful and Spanish Javier Bardem. The film also arranges a meeting for Liz and Felipe by having him knock her down with his car. Another part of the beautification process involved cleaning up parts of the story too gritty, too ugly or too real to watch. For example, we no longer see the effects of Liz actually living in these worldly locations, such as her difficulties with Wayan in Bali, she is a perpetual tourist.

Secondly, despite having a range of emotional material present in the book Eat, Pray, Love for some reason the filmmakers felt that this was not enough. A lot of conflict, especially in relation to Liz's time in Bali, is added to the film that was not in the book. Liz and Felipe have a number of arguments that, despite the acting prowess of Roberts and Bardem, feel contrived and out-of-place. It ruined the spirit of the original story which seemed to be a celebration of that fact that love can be different and wonderful and where you least expect it.

The effect of simplification is mostly seen in the scenes in Italy. In the book, Liz paints us a wonderful picture of her very rich social life in Rome; she has a wide variety of friends from different places. However, the film turns this diversity into an Italian version of friends- all her people exist as one social circle and hang out together to condense Liz's emotional connections with them all into one neat package.

The film Eat, Pray, Love transfers almost what is possible. We can easily trace the cardinal functions. The divorce, Liz's broken relation with David, her decision to take a yearlong travel to find her inner self, the part where she indulges herself in Italy, the ashram, the meditation and the prayers in India, her meeting with the medicine man and her relationship with Felipe in Bali, etc are examples of the "cardinal functions" as Barthes puts it (Allen 35). All these incidents define the narrative and form the crux of the narrative.

In the memoir, Elizabeth is an average looking, 32 year old woman with not much of an income as she is a not so famous writer. There is nothing quite extravagant about her as she even reveals herself while in Rome that "I may admit something not entirely flattering to myself, these Romans on the street aren't really giving me any second looks. Or even many first looks, for that matter" (Gilbert 67). Liz reveals that if she was beautiful or better looking, passers would perhaps give her a glance or two but they do not, implying that she is not the best looking woman. 
This is significant to why the memoir is more enjoyable than the film because as a reader, one's mental picture of a certain character is very important to his/her overall understanding of the story. Also, it is important to the story because you cannot have a wealthy looking actress play a middle-classed woman, which may not seem right.

In the film, however, Elizabeth Gilbert is played by the stunningly beautiful 43 year old Julia Roberts, who does not look like someone who should be playing the role of Liz.Roberts, looks too much like a wealthy, older woman, thus taking away the effect of the character. It contradicts the audiences' mental image of what the main character should look like. It takes away the essence of the story and makes the audience forget what Liz really is. Moreover, Elizabeth Gilbert in the memoir, Eat, Pray, Love is portrayed to be a friendly individual with an extra personal personality. In the film though, she is perceived as a socially awkward individual who doesn't seem to get along easily.

To begin with, Liz is perceived as a friendly individual throughout the book. This is seen when she meets Richard from Texas in India. When Liz is narrating her meeting with Richard, she states: "Groceries. That's the nickname Richard had given me. He bestowed it upon me the first night we met" (Gilbert 146). This reveals that Elizabeth and Richard hit things off the day they met, since they went out for dinner the following night. Also, she ate in front of him which is something not many girls do when they first meet a male.

The film Eat, Pray, Love completely contradicts this though. While Liz is seen as being a warm individual, especially when meeting Richard, the film portrays otherwise. The memoir reveals Liz hitting things off easily with Richard but the film shows Liz and Richard having a tough time getting close when they first meet, and the audience can still sense some tension each time they meet prior to their first meeting. This contradicts the character trait of Liz being extra personal because now she is being portrayed as socially awkward and that is not how her character is, disrupting the audience's perception of Elizabeth's character, making her seem almost as awkward. Furthermore, both Ryan Murphy and Elizabeth Gilbert demonstrate that Liz has definitely grown and developed as an individual however, the memoir reveals a much clearer and consistent growth the researcher personally found much easier to understand as opposed to the film. The film revealed Liz to develop into a more attentive being but still is seen as insecure and doubtful like her old self.

The catalysers are also mostly retained in the film though not all of them. The filmmakers chose to omit some incidents to give the film a clearer structure. For example, the wide range of friend circle that Liz possesses is not brought in to the movie. Liz mentions her friends and talks about their opinions and suggestions to her idea of taking a year long journey. In the movie only Delia is presented as a close friend. The movie also omits the part where Liz's sister visits her in Rome. Liz's description of her family, their childhood etc were also not shown. Liz's one month language learning class in Italy, the part where she dedicates the verses of Gurugita as a hymn of love and sincerity to her eight year old nephew Nick, the poet/plumber from New Zealand who gives Liz a handwritten note with instructions on freedom, the problems that she faces with Wayan the healer in Bali and the Indonesian pals Mario and Yudhi, the fake American road trip across Bali with Yudhi etc were also avoided in the movie.

Some of the informants were slightly changed to update the story and situate it in a different context. For example, Liz meets her Swedish friend Sofie in her language learning class in Rome and Sofie starts to get involved with the twin of her language master, Giovanni. Luca Spaghetti is a friend of Liz's college friend and Liz often mentions him even before meeting him, in the book. For Luca Spaghetti's birthday, Liz and her group of Italian friends gather together for an American-style thanksgiving feast at another couple's home in the countryside. But in the movie we see that the way in which Liz makes friends in Italy is presented in a different context. Liz meets Sofie by chance in a busy cafe. Sofie orders them cappuccinos and napoleons and they become good friends immediately. It is Sofie who introduces Giovanni to Liz in order to help her study Italian. Later on, Sofie gets romantically involved with Giovanni, and Luca Spaghetti is introduced as a friend of Giovanni's in a barber shop. The thanksgiving celebration takes place at Giovanni's home, since his mother is present. By introducing the changes the director makes sure that the meaning of the source material is not changed. But the form is changed slightly in order to meet the limitations of the movie.

Also in India, Liz easily become friends with Richard from Texas and often listens to his advices. He is presented as a confident man and whose advice often allows Liz to let go of all her worries. But in the movie we see that Liz and Richard do not get along well in the beginning. One who has not read the book will find Richard as an irritating man. Another example is the setting of the narrator's first meeting with Felipe. In the book Liz meets Felipe at a 
party where she was invited by Armenia, a Brazilian girl. But in the movie they first meet when Felipe knocks her down from her bicycle with his jeep and it is in the party they meet again and talk. A lot of conflict, especially in relation to Liz's time in Bali, is added to the film that was not in the book. Liz and Felipe have a number of arguments. The problem with her friend and healer, Wayan that is described in the book is omitted in the movie.

In the memoir, Gilbert solicits donations from her friends to try to support Wayan, a single mother whose divorced status leaves her socially and financially vulnerable in Bali. This can be seen as one of the strongest and most ethically compelling portion of Eat, Pray, Love and was the point in the book at which Gilbert vocalizes and acknowledges her status as an outsider. In the film version, Gilbert's gift to Wayan is used in the film as a kind of spider web, bringing all of Gilbert's experiences in Italy, India, and Indonesia together through her company with Wayan and her daughter Tutti. This is cleverly done with the double meaning of the spoken form of the word "tutti", which in Italian means "everybody" (Eat Pray Love).

Some other differences with regard to the plot are, when Liz sits in the floor and praysformally for the first time, in the book, she hears the answer as, "Go back to bed, Liz"(Gilbert 6). This is an answer she hears is a quite but direct answer to her prayer telling her that there is nothing she can do this moment so she might as well go back to bed and get some sleep. In the movie, when Liz prays, we immediately hear Julia Roberts' voice answering, "Go back to bed, Liz", which makes her sound like she's a little crazy and talkingto herself (Eat, Pray, Love). We completely miss the profoundness of the message she received.

In the memoir portion which deals with her life in Italy, Liz and Sophie eat a whole pizza each and order another in the birth place of pizza, Naples. In the movie, Liz and Sophie are going to Naples for pizza, but the explanation of why Naples is important is missing. They also only order one pizza and immediately begin talking about the weight they gained, completely disregarding how amazing this food is. But Gilbert's original version spends a great deal of time on this meal.

In the memoir Eat, Pray, Love, when keeping her romance with Felipe, Liz is completely sure about her feelings, actions and the next steps she is willing to take; the way it should be. Liz reveals her love for Felipe when narrating her romance and says "So me and my lover, we take off our shoes, we pile our small bags of belongings on the tops of our heads and we prepare to leap over the edge of the boat together, into the sea" (Gilbert 346). This signifies how much trust Liz had in her lover, which is fairly surprising due to the outcome of her last relationship and the condition it left her in. Here, we understand how much she has developed as an individual because she went from a ruined, wrecked, and broken down woman suffering from a broken heart to a strong, amiable one after meeting the right person. Also, a little confident now as she has her life under control

The film, on the other hand, portrays Elizabeth to still be overcome with insecurities and doubts from her past relationship interfere with her current one. When Felipe asks Liz to take a leap and go on a boat trip with him, her past emotions resurface and Liz becomes alldoubtful again due to the outcomes of her previous relationship. This detail discloses that although Liz has developed in the book, she has not developed much in the movie since she is still the same person she was in the beginning.

Some of the other difference are, in the novel, Elizabeth get a book deal to go on her trip. It is paid for by the advance. But the film glides pretty uneventfully through the rest of the events leading up to the three-country journey. The biggest departure here is the fact that the film makes no direct mention of a book deal. We do not even really see Gilbert writing all that much over the course of the film. Appearances being what they are, in the movie Liz does not even really seem to be that much of a writer. She is merely drifting along through the three countries because she wants to- not because she is making an obscene amount of money traveling the world so that she can spend it for the benefit of those less fortunate and pontificate about it.

Next difference is that, in the novel, Richard is likened to Foghorn Leghorn. But in the film, she compares him to James Taylor. In the novel, Liz finds it hard to sit through the one and half hour prayer in India. She gets through it by dedicating it as a hymn of pure love and sincerity to her eight year old nephew Nick. But in the film, he devotes it to seventeen year old fellow, Tulsi. In the novel, Liz met Felipe in Bali when she was invited to a gathering by the fellow Brazilian Armenia. But in the film, it was Felipe who ended up bumping Liz and her bike off the side of the road in his jeep, causing a little bit of irritation and tension when they met again at the party. In the memoir, Liz embarks on her Bali romance with Felipe and allows herself to love and be loved after learning to find pleasure in 
Italy and exorcising her demons in India. There was no hesitation or self-doubt. Divorced Felipe, also, does not waver in his devotion to Liz, At the end of the book she takes Felipe to a tiny island called Gili Meno, which she described as "one of the most important places in the world" (Gilbert 339). Whereas in the film, Liz is still wracked with insecurity at the thought of entering fully into the relationship with Felipe, and a shadow of doubt crossed over divorced Felipe's face as to whether or not he could allow himself to trust someone again. Here Felipe is shown to have trust issues, and so did Liz.

The film script seems to focus much more on the interpersonal relationships in the story than Gilbert did. The relationship between Gilbert and her ex-husband Steven is given a bit more depth here. Billy Crudup plays her husband as a restless guy who has not quite figured out what he wants to be just yet. While not without his charm, the young guy who does not know what he wants playing against the successful writer falls against the screen a bit lifelessly. That being said, the interaction here is far more interesting and far less bitter than Gilbert makes it feel in the book. The film could have done more to show Julia Roberts contrasted against the exotic locations and beautiful scenery. It would have played up more of the universality of the kind of journey the character Gilbert is going on. Instead of opting for a more unspoken journey, the film ends up trying to exist in stray dramatic interpersonal moments throughout the journey, including persistent feelings for her ex-husband and the boyfriend David, with whom Gilbert had had a brief affair.

The technique of flashback is used by many movies as well as novels since the past is an important factor in understanding the story. A movie or a novel either begins with a flashback or it may use it somewhere in between as the story progresses. Many modernist writers use the technique of flashback quite often in their work. In the case of Eat, Pray, Love Gilbert uses flashback to tell the readers about her relationship with her husband. The novel begins with the description of her divorce but it is only later that the readers come to know of the reason for divorce through the flashbacks. But it is to be noted that unlike the book, it is the movie version which uses flashbacks more. There are several instances where RyanMurphy uses this technique to convey to the audience about Liz's past. One instance that stands out is the scene where Liz goes to the wedding of Tulsi and she is reminded of her own marriage. For this, the director creates a scene where Liz and her ex-husband perform their wedding dance. Liz is clad in a green Indian saree which she wears for Tulsi's wedding but her husband is in his wedding suit. This explains that even though Liz walked out of her marriage, at times she gets reminded of her husband and their past life.

To keep the film to its standard length, the director takes course to larding or padding the text often with audiovisual pleasures exceeding narrative functionality. For example, in the movie Eat, Pray, Love the part where Liz indulges herself in the pleasures of Italy, trying out the delicious Italian food, eating pizzas and watching soccer game, etc are presented to the audience through a song sequence. Thus the director manages to stick to the time constrains of the movie without deviating much from the original source material.

Direct translation from literature to film is not possible because of the incredible change in the dimension and technique of the two media. Overall, although both Elizabeth Gilbert and Ryan Murphy divulge the role of Liz effectively in their own similar yet delightfully different works, the memoir surpasses the film due to a better job with specific elements. They did a great job in the revelation of the character of Elizabeth but Gilbert seems to have done the better job. To tackle with the constraints that limit an adapted film, the director brought out certain changes, while retaining the storyline. Thus Ryan Murphy's Eat, Pray, Love translates what is possible and it seem to be a faithful adaptation even though there are certain differences in the film, which is incorporated by the director to meet the limitations of the movie form and therefore to meet its success.

\section{Works Cited:-}

1. Abrams, M.H. A Glossary of Literary Terms. New Delhi: Cengage Learning, 2012. Print.

2. Desmond, John M., and Peter Hawkes. Adaptations: Studying Film and Literature. New York: McGraw Hill, 2006, Print.

3. Eat Pray Love. Dir. Ryan Murphy. Prod. Dede Gardner. Perf. Julia Roberts, Javier Bardem,

4. Richard Jenkins, Billy Crudup and James Franco. Columbia, 2010. Film.

5. Gilbert, Elizabeth. Eat Pray Love: One Woman's Search For Everything Across Italy, India and

6. Indonesia. London: Bloomsbury, 2006. Print. 